\title{
AC 2011-472: OVERCOMING THE CHALLENGES OF IMPLEMENTING TECHNICAL COMMUNICATION IN A CAPSTONE SENIOR DESIGN COURSE
}

G. Scott Duncan, Valparaiso University

Assistant Professor of Mechanical Engineering

Dr. Mark M. Budnik, Valparaiso University

Jeffrey Will, Valparaiso University

Prof. Peter E. Johnson, Valparaiso University

Dr. Shahin S. Nudehi, Valparaiso University

(c)American Society for Engineering Education, 2011 


\title{
Overcoming the Challenges of Implementing Technical Communication in a Capstone Senior Design Course
}

\begin{abstract}
Numerous publications have emphasized the importance of technical communication skills in the field of engineering. Capstone Senior Design courses are typically selected to evaluate and enhance the technical communication skills of engineering students. To effectively implement technical communication into a Capstone Senior Design course, four main challenges must be overcome. The first challenge is to provide students with consistent, quality feedback. The second challenge is to overcome resource constraints to effectively implement communication instruction in the course. The third challenge is to provide students with exposure to multiple communication mediums and audiences. The fourth challenge is to develop techniques to motivate students to improve their communication skills. This paper provides the techniques used in the Valparaiso University Capstone Senior Design course to address all four of these challenges.
\end{abstract}

\section{Introduction}

Numerous publications have emphasized the importance of technical communications skills in the field of engineering. Results of a 1999 survey from engineering graduates who have been in the workforce from three to five years showed that "64 percent of these engineers' overall work time is spent on some form of communication"1. In a 2005 study based on a focus group of 50 individuals representing both academic and non-academic engineers, communication competency ranked as the second most important engineering attribute, behind only technical competency $^{2}$. ABET also recognizes the need for engineers to develop communication skills as Criterion 3 identifies that students attain "an ability to communicate effectively" as a required program outcome ${ }^{3}$. Additionally, the importance of communication skills to the practicing engineer is predicted to remain important in the future. The National Academy of Engineering 2004 report, "The engineer of 2020: visions of engineering in the new century" ${ }^{4}$, when describing the attributes of engineers in 2020 states that, "As always, good engineering will require good communication."

Because technical communication skills are so vital to engineers, many studies have been completed to investigate the effectiveness of technical communication pedagogical methods implemented in engineering curriculums. These studies generally focus on two areas of technical communication: written communication skills ${ }^{5-8}$ and oral presentation skills ${ }^{9-11}$. Furthermore, Capstone Senior Design courses, which are often based on multi-disciplinary teams functioning in an environment that attempts to mimic actual workplace and design process conditions, are often selected as a section of the curriculum to evaluate and enhance the technical communication skills of engineering students. Accordingly, many studies have been completed to investigate the effectiveness of technical communication pedagogical methods implemented in these courses ${ }^{12-14}$.

Although Capstone Senior Design courses are a conducive environment for teaching technical communication skills to engineering students, an effective implementation faces many challenges. Students must have the time to complete technical communication assignments 
while also mastering the design process and completing a project with intensive design and manufacturing content. Faculty must create assignments in a variety of technical communication mediums that allow them to provide constructive feedback while working under resource constraints. In addition, the evaluation of technical communication skills must be consistent across multiple faculty members and the assignments must allow faculty to evaluate and provide technical communication feedback to individuals as well as to complete teams so that individuals with weak communication skills cannot remain unobserved in a team environment. Finally, faculty must emphasize and students must realize the importance of communication to the design process, the success of their project, and their future success in the workplace.

In this paper, we describe the strategies employed at Valparaiso University (VU) to overcome the challenges of implementing technical communication in a Capstone Senior Design course. The paper begins with a brief summary of the Capstone Senior Design course at VU and then identifies each significant technical communication implementation challenge along with the relevant implementation strategy. Finally, the results of a student survey to assess the effectiveness of the technical communication instruction in the VU Capstone Senior Design course are presented.

\section{Background}

The Capstone Senior Design course at VU was introduced in its present form in the fall of 2000 as a two course sequence: a three credit course in the fall semester and a two credit course in the spring semester. Both courses are required for all electrical engineering, computer engineering and mechanical engineering students and with the exception of special cases, the courses are taken in sequence during the senior year. The first course focuses on definition, design, and analysis of the system and the second course focuses on the manufacture and testing of the system; therefore, at the end of the two course sequence, each student will have participated in the development of an actual system, from conceptualization through testing. For each of the courses, the students are required to attend two to four hours of instruction per week, consisting of lectures, presentations, and team meetings with their advisor. Technical communication is an integral part of both courses.

The College of Engineering at VU has made a significant commitment to the Capstone Senior Design course in terms of both faculty teaching load and financial support. Approximately 50 students are enrolled in the course each year and are divided into multi-disciplinary teams of five to seven students. Each team is assigned a mechanical or electrical and computer engineering faculty member as a faculty advisor; therefore, four or five faculty members are assigned to the course each year with each faculty member acting as team advisor to two teams. If a team is assigned an electrical and computer engineering faculty member as team advisor, a mechanical engineering faculty member is assigned as a technical advisor and vice-versa. Additionally, although outside funding is occasionally available from industry sponsors or research funds, the majority of funding is provided by the VU College of Engineering and divided among the teams.

At the beginning of the year, students and Capstone Senior Design faculty propose potential projects. Based on educational merit, acceptable scope, and budgetary constraints, certain projects are excluded and a final project list is presented to the students who list the projects in order of preference. The Capstone Senior Design faculty then finalize the project teams and 
assign a faculty advisor to each team. Projects can take on several forms. For example, research funded projects have been completed to develop a solar thermal reactor and a device to help children with autism integrate into standard classroom settings. In addition, many systems are developed for entry into student design competitions, such as robots to enter the Jerry Sanders Design Competition $^{15}$ or for philanthropic pursuits, such as the development of windmills to provide power to a village in Nicaragua. Finally, some projects are simply based on interesting ideas, such as systems to determine the combination of padlocks, sort change, or develop a new game.

\section{Technical communication challenges and implementation strategies}

Four major challenges to implementing technical communication in the Capstone Senior Design course at VU were identified. First, faculty must provide consistent, quality feedback on technical communication skills. Second, faculty must be able to provide constructive feedback while working under resource constraints. Additionally, students must have the time to complete technical communication assignments while also mastering the design process and completing a project with intensive design and manufacturing content. Third, the course content must develop a complete communicator capable of addressing diverse audiences over a variety of communication mediums. Finally, faculty must motivate the students to improve their technical communication skills. Each of these challenges along with pertinent strategies to address the challenges is discussed below. To provide a foundation for the discussion, a brief description of the twenty-two Capstone Senior Design course assignments is provided in Appendix A.

\subsection{Challenge one: provide consistent, quality feedback to all students}

For students to improve their communication skills, Senior Design faculty members must provide consistent, high quality feedback to all students. This task is complicated at VU and many other universities by two main factors: 1) multiple faculty members teach the Capstone Senior Design course, and 2) assignments in a course that emphasizes team results can mask individual performance.

Providing consistent feedback when multiple faculty members teach the course is important. At many universities, student interaction levels are high. Therefore, when students with different faculty advisors compare grades and feedback, they can become confused due to varying grading techniques and inconsistent criticism and advice. Moreover, during oral presentations at VU, students receive feedback from all faculty members on their presentation content and presentation skills. Again, conflicting opinions and varying feedback can be confusing to the students.

In addition to the complications that arise due to multiple faculty members teaching the course, it is also critical that students receive individual feedback to assess and improve their communication skills. Similar to most Senior Design courses, the VU course emphasizes team performance, and it has been determined that team assignments can mask communication deficiencies of individual students. This is especially prevalent in the area of technical writing where the faculty advisor may not know the author of each paper section. Therefore, it is important to provide communication feedback to both teams and individuals. 
Multiple techniques are used to improve the consistency of faculty technical communication feedback. First, VU Senior Design faculty have a weekly meeting to discuss project performance and calibrate general grading strategies between faculty members. Additionally, grading rubrics have been created for all assignments (see Appendix B for an example rubric). To eliminate conflicting comments and grades when evaluating oral presentations, each individual faculty advisor collates all comments and grades from all faculty members and forwards one grade and screened comments to the appropriate team. Finally, Senior Design faculty participate in a calibration session for writing assignments. During this session, a common writing assignment is commented and graded. Then, Senior Design faculty discuss the results with the goal of developing a common grading standard.

When implementing technical communication in a Capstone Senior Design course, it is also critical to provide high quality feedback to students in the area of technical communication. Four techniques are used at VU to accomplish this feat. First, approximately thirty percent of the class periods are reserved for team meetings. Therefore, faculty advisors can directly observe the communication skills of each team member and provide suggestions. Moreover, during team meetings, faculty member will often ask the students to brainstorm and implement techniques to improve their group communication skills.

Second, every student has their individual communication skills evaluated. In addition to group assignments, individual assignments are created in the technical writing and oral presentation mediums. For example, in the first semester, each individual student is required to write a summary of one of three group activities: 1) the development of realistic design constraints, 2) an alternative solution analysis exercise, or 3) a hazard analysis. Additionally, in the second semester each individual student must write a project status report. In the oral presentation medium, all students are required to present two oral progress reports (five minutes each) to the assembled faculty and class. Approximately 30 percent of the total assignments and each student's final grade are based solely on individual performance. The remaining assignments require group collaboration skills and teamwork.

Third, because students often interact differently when a faculty member is not present, students evaluate the performance of each of their team members in the form of a performance review. The students complete these performance reviews three times each semester, rating the performance and identifying the strengths and weaknesses of their teammates. All final course grades are adjusted based on these reviews. Furthermore, these performance reviews allow the faculty advisor to identify areas that require improvement, enabling them to provide suggestions to both the entire team and individuals on a one-on-one basis. It has been observed that many team members rate communication skills as an area of potential improvement for themselves or their teammates.

Fourth, whether the assignments are individual or group based, students have multiple opportunities to implement faculty feedback, improve, and be re-evaluated. For example, the critical design report contains sections from the conceptual design report. The conceptual design report contains sections based on previous assignments such as the hazard analysis, realistic design constraints, and alternative solution analysis. Additionally, students provide multiple oral 
individual and team presentations throughout the course providing students the opportunity to improve and implement suggestions.

\subsection{Challenge two: overcome faculty and student resource constraints}

To successfully incorporate technical communication content into Capstone Senior Design courses, it is essential to develop an implementation strategy that optimizes student learning when both faculty and student resources are limited. In the Senior Design course at VU, faculty have a large time commitment in support of the technical aspects of the course. They lecture, grade, organize the course, oversee team meetings, provide technical advice and support, order

parts, and support the manufacturing and testing of the systems. Students also have a large time commitment in support of the technical course content. When considering the student's lack of experience, the specification, design, analysis, manufacture, and testing of even modest systems is a time intensive endeavor. Additionally, both students and faculty must complete the requirements of the Senior Design course while meeting the requirements of their other courses. Finally, technical writing and providing valuable feedback on technical writing assignments is particularly time consuming. For instance, in providing quality feedback on a one page writing assignment, faculty can invest as much as one hour of time. Consequently, the challenge is to overcome student and faculty resource constraints to provide excellent instruction and feedback in the technical communication area.

Two main techniques are used in the Senior Design course at VU to optimize the use of student and faculty resources. First, all writing assignments have a page limit and all oral presentations have a time limit. Moreover, a significant reduction in the assignment grade is applied if these limits are violated. Page and time limits are intended to force students to revise their original work providing an additional benefit of improving the quality of their submissions.

Consequently, faculty workload is reduced because it requires less time to grade and provide feedback on shorter, higher quality submissions.

Second, to reduce the time faculty spend grading and providing feedback on written assignments, high quality submissions are encouraged. All individual writing assignments require a review from another student ${ }^{16}$, an initial submission, and possibly a final submission. For all written assignments, both the writer and reviewer receive the same grade. This improves the quality of the initial submission because: 1) students typically work more diligently when another student's grade is dependent on their work, and 2) a reviewed and revised work is generally of higher quality than the original work. Also, when an initial submission of sufficient quality is received, bonus points are awarded, and a final submission is not required. Again, this procedure motivates students to submit higher quality initial submissions because their workload is reduced (no final submission required) and they earn bonus points. An additional benefit to student reviewing is that the reviewer has the opportunity to learn from the writer and vice-versa. 


\subsection{Challenge three: develop a complete communicator}

If students are to become well-rounded communicators, it is vital that they are capable of communicating in all mediums to a large variety of audiences. Traditionally, Senior Design courses have focused on two mediums of technical communication: 1) written communication in the form of a final project report, and 2) oral presentation in the form of a final project presentation. Group dynamics, teamwork, and secondary communication skills such as poster presentation and video presentation are often not emphasized or excluded from the course. Additionally, some Senior Design courses provide an audience limited to student peers and faculty; however, to become a complete communicator, an individual must be able to address a broad audience ranging from the general public (who have little engineering knowledge) to practicing engineers (who are experts in their field). The challenge is to incorporate material from all communication mediums into already crowded course content and to provide students with the opportunity to interact with a variety of audiences.

In the Senior Design course at VU, five technical communication mediums are addressed and the students are required to communicate with a variety of audiences. The first communication medium to which the students are introduced is group dynamics and teamwork. Initially, the students receive a lecture that emphasizes the importance of teamwork, identifies common problems that occur in teams, and defines potential team member personalities. Potential personalities include serious students, students who enjoy humor, domineering students, lazy students, etc... After receiving the lecture, student teams brainstorm ideas on how they will contend with each personality that may exist on their team. In addition to the instruction students receive on teamwork, almost every assignment provides the opportunity for students to practice and improve upon their teamwork skills. For example, students work in teams to define their system specifications, determine design constraints, identify hazards, develop and evaluate designs, develop testing criteria, manufacture their systems, and test their systems.

In general, the students in the Capstone Senior Design course at VU develop their teamwork skills by interacting with their team members and faculty advisors. However, students also have the opportunity to apply their teamwork skills to a larger audience including project customers in the form of faculty members not associated with the course, representatives of companies that sponsor projects, or charitable organizations that benefit from projects. For example, one student team who designed a windmill to provide power to lights and refrigerators at an orphanage in Nicaragua worked with the local engineer and orphanage administrators to specify and install the system.

The second technical communication medium that is addressed is technical writing. Because students have received technical writing instruction at prior points in the curriculum, no technical writing instruction is currently included in the course content. However, an assortment of writing assignments are required that provide students with an opportunity to improve their individual writing abilities and learn group writing skills. For example, individual writing assignments include a project status report and a summary report on realistic design constraints, the hazard analysis, or the alternative solution analysis. Additionally, group writing assignments include the conceptual design report, critical design report, and test report. 
It is also important that students learn to write for a variety of audiences. Therefore, the audiences for the writing assignments are varied and identified in the instructions and include nontechnical customers, supervisors, and engineers and technical personnel. Additionally, to receive feedback from as many audiences as possible, student teams are encouraged to submit written documentation of their work to student design competitions and relevant conferences. For instance, the student team developing a device to help children with autism integrate into standard classrooms submitted an abstract to the Rehabilitation Engineering and Assistive Technology Society of North America (RESNA) Annual Conference ${ }^{17}$ and the Butler Undergraduate Research Conference ${ }^{18}$ for consideration.

The third technical communication medium that is included in the course content is oral presentation skills. Prior to completing any oral presentation assignments, the students receive a lecture on presentation skills. Subsequently, once each semester they are required to present an individual five minute progress report to the Senior Design faculty and students. Also, multiple group presentations are integrated throughout the course and include presentations on their design concept, their design justification based on engineering analysis, and a final project presentation at the end of the course. In addition to formal presentations, students are also required to provide informal presentations at the VU College of Engineering Design Exposition and during prospective student tours.

The audience for oral presentations is very diverse. For oral progress reports and group presentations the audience always includes Senior Design faculty and students but often includes additional engineering faculty and external customers. For informal presentations, the audience is the general public. Occasionally, the students will present their projects at relevant conferences $^{18,19}$ or the VU Celebration of Undergraduate Scholarship where the audience is faculty and students from a variety of disciplines and universities.

Two final, often overlooked communication mediums that are incorporated in the VU Senior Design course are poster and video presentations. Students are provided with one class period of video editing instruction along with instructions for producing quality video and technical posters. The audience for the posters and videos is the general public as the posters are displayed in the hallways of the College of Engineering at VU and the videos are played at the VU College of Engineering Design Exposition. Occasionally, the posters are presented at relevant conferences $^{18,19}$.

\subsection{Challenge four: motivate engineers to improve their communication skills}

If students are to improve their technical communication skills, it is essential that they attain the requisite motivation to improve their abilities in this area. When engineering students begin the Senior Design course at VU, many of them lack this motivation. They believe that their future success is based solely upon their technical skills. Therefore, they often see technical communication instruction and assignments as unnecessary work that is a hindrance to the successful completion of their project. Additionally, some students falsely believe that they are already good technical communicators and do not need to improve their skills in the area. They confuse social communication, such as texting, writing e-mails, or friendly conversation, with technical communication which requires the ability to communicate technical information to a 
diverse audience in a clear and concise manner. This is often exemplified as a lack of formality, organization, and flow in their submitted assignments. Moreover, they confuse humanities based communication where they have had previous success, such as essays and speeches, with technical communication, such as technical presentations and reports, where they are lacking fundamental skills. As students progress in the Capstone Senior Design course and realize they lack fundamental technical communication skills, they can lose motivation as they question whether it is possible to reach the standards required of engineers. Thus, the fourth challenge is to motivate Senior Design students to improve their technical communication skills.

To motivate students to improve their technical communication skills, it is essential that faculty convey to students that they are serious about communication instruction. In the Senior Design course at VU, faculty convey their seriousness first by incorporating technical communication evaluation as a significant portion, approximately fifty percent, of the overall course grade. Additionally, every grading rubric emphasizes technical communication skills along with technical content. Finally, during lectures and team meetings, students are constantly reminded of the importance of communication skills.

The Senior Design course structure also emphasizes the importance of communication skills. Specific milestones where students must communicate (such as oral progress reports, project status reports, design presentations, and milestone demonstrations) are incorporated into the course schedule. Specific milestones, such as design presentations, require students to adequately communicate their project information before they can proceed. For example, until a design is approved by a faculty advisor, teams are not allowed to order parts or begin the manufacturing of the system.

\section{Student Survey Results}

A student survey was performed to assess the effectiveness of technical communication instruction in the Senior Design course at VU. Forty-five out of fifty-one Senior Design students returned their surveys. The pertinent survey questions, rating scale for each question, and results are shown in Table One. Overall, the survey results show that students believe their experience in the course improved their technical communication skills. This is supported by two factors. First, based on the results of question seven, the students strongly believe that their technical communication skills increased in the Senior Design course. It should be noted that question seven received the highest score on the student survey. Second, each of the seven survey questions received a positive rating signifying that students believe their technical communication skills in multiple areas were improved due to their participation in the course.

The survey results provide additional positive feedback for the technical communication instruction in the Senior Design course. In general, students believed that the grading was consistent between faculty members (see question one) and the quality of feedback they received was beneficial (see questions two and three). Additionally, the students were motivated to improve their technical communication skills (see questions four and six). Finally, the students understood that they were being introduced to a variety of technical communication mediums (see question five). 
Table One: Student Survey Results

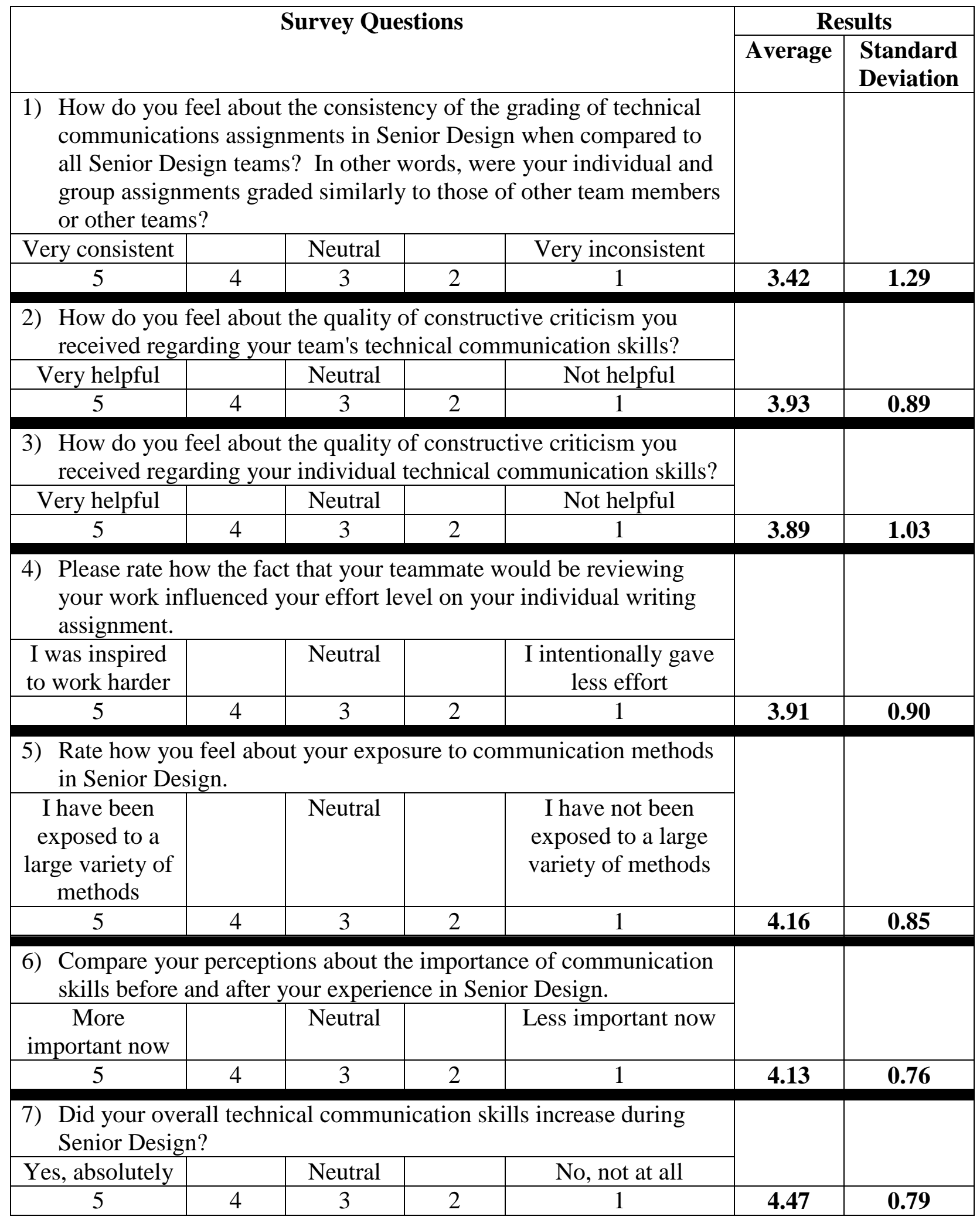




\section{Conclusions}

The ability to communicate effectively is essential to any engineer and Capstone Senior Design courses are a good point in the curriculum to emphasize the importance of communication skills and provide technical communication instruction. However, multiple challenges must be overcome to implement technical communication instruction in Capstone Senior Design courses including: 1) providing consistent, quality feedback to students, 2) overcoming faculty and student resource constraints to incorporate technical communication into the Senior Design course, 3) providing students with exposure to multiple communication mediums and audiences, and 4) developing techniques to motivate students to improve their communication skills. This paper discussed multiple techniques employed at VU to overcome these challenges.

Additionally, results of a student survey show the students believe technical communication instruction in the Capstone Senior Design course at VU strongly improved their technical communication skills. In the future, VU Senior Design faculty will continue to research new communication pedagogical innovations for incorporation into the Senior Design course and evaluate specific communication assignments and instruction to identify areas of improvement.

\section{Acknowledgements}

The authors would like to acknowledge the many VU College of Engineering faculty members who have contributed to the development of the Capstone Senior Design course.

\section{Bibliography}

1. Sageev, P. and Romanowski, C., "A Message from Recent Engineering Graduates in the Workplace: Results of a Survey on Technical Communication Skills," Journal of Engineering Education, October 2001, pp. 685-693.

2. Davis, D., Beyerlein, S., and Davis, I., "Development and Use of an Engineer Profile," Proceedings of the 2005 American Society for Engineering Education Annual Conference and Exposition, 2005, Portland, Oregon.

3. ABET Engineering Accreditation Commission, Criteria for Accrediting Engineering Programs, December 2008, Baltimore, MD: ABET, Inc.

4. National Academy of Engineering, The Engineer of 2020, Vision of Engineering in the New Century, 2004, Washington, DC, The National Academies Press.

5. Yalvac, B., Smith, H., Troy, J., and Hirsch, P., "Promoting Advanced Writing Skills in an Upper-Level Engineering Class," Journal of Engineering Education, April 2007.

6. Manion, W. and Adams, D., "When Less is More: Integrating Technical Writing Instruction in a Large, FirstYear Engineering Course," Proceedings of the 2005 American Society for Engineering Education Annual Conference and Exposition, 2005, Portland, Oregon.

7. Boyd, G. and Hassett, M., "Developing Critical Writing Skills in Engineering and Technology Students," Journal of Engineering Education, October 2000, pp. 409-412.

8. Sharp, J., Olds, B., Miller, R., Dyrud, M., "Four Effective Writing Strategies for Engineering Classes," Journal of Engineering Education, January 1999, pp. 53-57.

9. Dannels, D., "Teaching and Learning Design Presentations in Engineering: Contradictions Between Academic and Workplace Activity Systems," Journal of Business and Technical Communication, Vol. 17, No. 2, April 2003, pp. 139-169.

10. Dannels, D., "Communication Across the Curriculum and in the Disciplines: Speaking in Engineering," Communication Education, Vol. 51, No. 3, July 2002, pp. 254-268.

11.Piirto, J., "Speech: An Enhancement to (Technical) Writing," Journal of Engineering Education, January 2000, pp. 21-23. 
12.Paretti, M., "Teaching Communication in Capstone Design: The Role of the Instructor in Situated Learning," Journal of Engineering Education, October 2008, pp. 491-503.

13. Helbling, J., Lanning, D., and Madler, R., "Integrating Communications into Team-Taught Senior Design Courses," Proceedings of the 2005 American Society for Engineering Education Annual Conference and Exposition, 2005, Portland, Oregon.

14. Norback, J., Forehand, G., Jernigan, S., and Quinn, A., "Teaching Workplace Communication in Senior Design,", Proceedings of the 2002 American Society for Engineering Education Annual Conference and Exposition, 2002, Montreal, Canada.

15. Jerry Sanders Creative Design Competition, 27 Dec. 2010, <http://dc.cen.uiuc.edu>.

16. Wheeler, E. and McDonald, R., "Writing in Engineering Courses," Journal of Engineering Education, October 2000, pp. 481-486.

17. Rehabilitation Engineering and Assistive Technology Society of North America, 31 Dec. 2010, $<$ http://resna.org/>.

18. Butler Undergraduate Research Conference, 31 Dec. 2010, < http://www.butler.edu/undergrad-researchconference/>.

19. American Society for Engineering Education Illinois-Indiana Section Conference, 31 Dec. 2010, < http://ilin.asee.org/>.

\section{Appendix A: Brief Description of Capstone Senior Design Project Assignments}

\section{Semester 1}

Work Breakdown Structure: As a team, students create a work breakdown structure of their system where their project is broken down into subassemblies and subcomponents and presented in a tree format.

Project Schedule: As a team, students use Microsoft Project to develop a Gantt chart for their project and are required to update the chart as their project progresses.

System Design Requirements Document: As a team, students identify the necessary requirements to meet their customer objectives and develop a system specification.

Realistic Design Constraints: As a team, students identify the design constraints (budgetary, environmental, sustainable, social, political, health and safety, manufacturability, ethical, and legal) that apply to their project and system.

Hazard Analysis: As a team, students use a Failure Modes and Effects Analysis (FMEA) to identify potential safety hazards, the effects of failure, the severity of failure, the probability of failure, and the current or potential design controls to eliminate failures of their system.

Alternative Solutions Analysis: As a team, students brainstorm and evaluate multiple solutions to their design problem.

Writing Assignment: As individuals, students write and review a two page paper which summarizes the group results for the realistic design constraints, hazard analysis, or alternative solution analysis assignments. 
Conceptual Design Presentation: As a team, students orally present their concept for their system, emphasizing how they meet all design requirements, have reduced potential hazards, and are within all required design constraints.

Conceptual Design Report: As a team, students create a written technical report that summarizes their concept for the system, emphasizing how they meet all design requirements, have reduced potential hazards, and are within all required design constraints.

Critical Design Presentation: As a team, students orally present their final system design, including the required engineering analysis to justify that the design will meet the required specifications.

Critical Design Report: As a team, students create a written technical report that summarizes their final system design, including the required engineering analysis to justify that the design will meet the required specifications.

Milestone Demonstration: As a team, students manufacture and present a prototype of a critical subsystem.

Oral Progress Reports: As individuals, students provide a five minute presentation that updates the course participants on the status of their team's project. A question and answer period follows the presentation.

\section{Semester 2}

Project Status Reports: As individuals, students write and review a one page technical report that summarizes the status of their project.

Milestone Demonstration: As a team, students manufacture and present a prototype of a critical subsystem.

Final Test Plan: As a team, students develop a test plan for their system that assures all system design requirements have been met if the system passes all tests.

Video: As a team, students develop a five minute video that summarizes their entire project.

Poster: As a team, students create a technical poster that summarizes their entire project.

Design Documentation: As a team, students collate and organize all relevant design documentation including assembly prints, manufacturing prints, electrical schematics and prints, reports, etc...

Final Design Presentation: As a team, students present their final, working system prototype to the faculty advisor, students, and customers. 
Final Oral Report: As a team, students provide a twenty-five minute presentation that summarizes their entire project.

Oral Progress Reports: As individuals, students provide a five minute presentation that updates the course participants on the status of their team's project. A question and answer period follows the presentation.

\section{Appendix B: Example Rubric (Critical Design Presentation)}

\begin{tabular}{|c|c|c|c|c|c|}
\hline & 1 & 2 & 3 & 4 & Total \\
\hline Organization & $\begin{array}{l}\text { Audience cannot } \\
\text { understand } \\
\text { presentation because } \\
\text { there is no sequence of } \\
\text { information. }\end{array}$ & $\begin{array}{l}\text { Audience has difficulty } \\
\text { following presentation } \\
\text { because presentation } \\
\text { jumps around. }\end{array}$ & $\begin{array}{l}\text { Student presents } \\
\text { information in logical } \\
\text { sequence which } \\
\text { audience can follow. }\end{array}$ & \begin{tabular}{|l} 
Student presents \\
information in logical \\
sequence. Uses \\
presentation outline at \\
beginning and \\
summarizes contents at \\
ending.
\end{tabular} & \\
\hline $\begin{array}{l}\text { Subject } \\
\text { Knowledge }\end{array}$ & $\begin{array}{l}\text { Student does not have } \\
\text { grasp of information, } \\
\text { cannot answer } \\
\text { appropriate questions } \\
\text { about subject. }\end{array}$ & $\begin{array}{l}\text { Student is } \\
\text { uncomfortable with } \\
\text { information, answers } \\
\text { rudimentary questions, } \\
\text { but cannot elaborate. }\end{array}$ & $\begin{array}{l}\text { Student is at ease and } \\
\text { answers questions with } \\
\text { explanations and } \\
\text { elaborations. }\end{array}$ & $\begin{array}{l}\text { Student demonstrates } \\
\text { more knowledge than } \\
\text { required by ans wering, } \\
\text { explaining, and } \\
\text { elaborating on } \\
\text { questions. }\end{array}$ & \\
\hline Visual Aids & $\begin{array}{l}\text { Student's visual aids } \\
\text { do not support } \\
\text { presentation. }\end{array}$ & $\begin{array}{l}\text { Visual aids } \\
\text { occassionally } \\
\text { contradict student's } \\
\text { presentation. } \\
\text { Presentation contains } \\
\text { unnecessary } \\
\text { information. } \\
\end{array}$ & $\begin{array}{l}\text { Student's visual aids } \\
\text { relate to the } \\
\text { presentation. }\end{array}$ & $\begin{array}{l}\text { Student's visual aids } \\
\text { explain and reinforce } \\
\text { the presentation. }\end{array}$ & \\
\hline Mechanics & $\begin{array}{l}\text { Presentation has } 3 \text { or } \\
\text { more incorrect } \\
\text { spellings, grammar, } \\
\text { punctuation, or } \\
\text { formatting is sues. }\end{array}$ & $\begin{array}{l}\text { Presentation has } 2 \\
\text { incorrect spellings, } \\
\text { grammar, punctuation, } \\
\text { or formatting is sues. }\end{array}$ & $\begin{array}{l}\text { Presentation has } 1 \\
\text { incorrect spellings, } \\
\text { grammar, punctuation, } \\
\text { or formatting issues. }\end{array}$ & $\begin{array}{l}\text { Presentation has no } \\
\text { incorrect spellings, } \\
\text { grammar, punctuation, } \\
\text { or formatting is sues }\end{array}$ & \\
\hline Eye Contact & $\begin{array}{l}\text { Student makes minimal } \\
\text { eye contact, and } \\
\text { primarily reads from } \\
\text { presentation slides. }\end{array}$ & $\begin{array}{l}\text { Student maintains } 50 \% \\
\text { eye contact, and } 50 \% \\
\text { to the slides. }\end{array}$ & $\begin{array}{l}\text { Student maintains } 75 \% \\
\text { eye contact and } \\
\text { demonstrates, "Touch, } \\
\text { Turn, Talk" throughout } \\
\text { presentation. }\end{array}$ & $\begin{array}{l}\text { Student maintains } 90 \% \\
\text { eye contact and } \\
\text { demonstrates, "Touch, } \\
\text { Turn, Talk" throughout } \\
\text { presentation. }\end{array}$ & \\
\hline $\begin{array}{l}\text { Verbal } \\
\text { Techniques }\end{array}$ & $\begin{array}{l}\text { Student mumbles or } \\
\text { incorrectly pronounces } \\
\text { terms. Student speaks } \\
\text { too quietly for } \\
\text { audience in the back of } \\
\text { the room to hear. }\end{array}$ & $\begin{array}{l}\text { Student mumbles or } \\
\text { incorrectly pronounces } \\
\text { terms. Student speaks } \\
\text { quietly, and it is } \\
\text { difficult (but possible) } \\
\text { for the room to hear. }\end{array}$ & $\begin{array}{l}\text { Student speaks too } \\
\text { fast. Voice is clear and } \\
\text { pronounces most } \\
\text { words correctly. All } \\
\text { audience members can } \\
\text { hear presentation. }\end{array}$ & $\begin{array}{l}\text { Student rate of speech } \\
\text { is appropriate. Voice is } \\
\text { clear and pronounces } \\
\text { all words correctly. All } \\
\text { audience members can } \\
\text { hear presentation. }\end{array}$ & \\
\hline $\begin{array}{l}\text { System } \\
\text { Design } \\
\text { Overview }\end{array}$ & $\begin{array}{l}\text { Not all sub-systems are } \\
\text { presented }\end{array}$ & $\begin{array}{l}\text { Presents sub-systems, } \\
\text { but no high-level } \\
\text { description of system }\end{array}$ & $\begin{array}{l}\text { Good sub-system } \\
\text { overview, but } \\
\text { inadequate high-level } \\
\text { description }\end{array}$ & $\begin{array}{l}\text { Completely describes } \\
\text { top-level and sub- } \\
\text { systems, and their } \\
\text { interaction }\end{array}$ & \\
\hline $\begin{array}{l}\text { System } \\
\text { Design and } \\
\text { Analysis } \\
\end{array}$ & $\begin{array}{l}\text { System design is } \\
\text { incomplete }\end{array}$ & $\begin{array}{l}\text { Sub-systems designed, } \\
\text { but analysis is } \\
\text { inadequate }\end{array}$ & $\begin{array}{l}\text { Sub-systems and top- } \\
\text { level designed, } \\
\text { analysis is acceptable }\end{array}$ & $\begin{array}{l}\text { Sub-systems and top- } \\
\text { level designed, } \\
\text { analysis is excellent }\end{array}$ & \\
\hline Teamwork & $\begin{array}{l}\text { Less than half of the } \\
\text { team members } \\
\text { contribute. }\end{array}$ & $\begin{array}{l}\text { Most team members } \\
\text { contribute. }\end{array}$ & $\begin{array}{l}\text { All team members } \\
\text { contribute, but not } \\
\text { equal. }\end{array}$ & $\begin{array}{l}\text { All team members } \\
\text { present and contribute } \\
\text { equally. }\end{array}$ & \\
\hline Q \& A & $\begin{array}{l}\text { Cannot answer } \\
\text { questions }\end{array}$ & $\begin{array}{l}\text { Answers questions, } \\
\text { but behaves improperly } \\
\text { during Q \& A session }\end{array}$ & Meets expectations & $\begin{array}{l}\text { Far exceeds } \\
\text { expectations }\end{array}$ & \\
\hline & $\mathrm{D}=24-27$ & $C=28-31$ & $B=32-35$ & $\mathrm{~A}=36-40$ & \\
\hline
\end{tabular}

